\title{
PERFORMING (IN)SANITY: UN-DOING GENDER IN JANET FRAME'S AN ANGEL AT MY TABLE
}

\section{Laura de la Parra Fernández}

\author{
Universidad Complutense de Madrid
}

Like tuberculosis, insanity is a kind of exile.

SUSAN SONTAG

\begin{abstract}
This essay explores madness as a performative practice in Janet Frame's An Angel At My Table (1981) as a way to escape from gender conventions. Following Shoshana Felman and Suzette Henke, I will look at how Frame deconstructs and reconstructs a new identity by giving up female gender conventions - especially sexuality and the normative female body. In the second part of this article I analyse how, by omitting an actual account of her stay in numerous mental institutions in her autobiography, she reshapes and "remembers" the image that she wants to portray of herself.
\end{abstract}

Keywords: Gender studies, Janet Frame, life writing, performativity, madness.

\section{Resumen}

Este ensayo explora la locura como práctica preformativa en An Angel At My Table de Janet Frame (1981) como forma de escapar de las convenciones de género. Siguiendo a Shoshana Felman y a Suzette Henke, observaremos cómo Frame reconstruye una nueva identidad al renunciar a las convenciones del género femenino - en especial, la sexualidad y el cuerpo femenino normativo. En la segunda parte de este artículo se analiza cómo al omitir en su autobiografía el relato de su estancia en diversas instituciones mentales, restaura y se hace cargo de la imagen que quiere proyectar de sí misma.

Palabras clave: estudios de género, Janet Frame, escritura autobiográfica, performatividad, locura.

The philosopher Ian Hacking claims that "[i]n every generation there are quite firm rules on how to behave when you are crazy" (quoted in Appignanesi 4). Although I do agree with this quote, I would say that this is a consequence of the established ways to perceive madness and to deal with it. In her famous study on female madness The Female Malady (1987), Elaine Showalter defines madness as "offenses against implicit understandings of particular cultures/residual rule-breaker / labelled as mad - stabilized and fixed, launching the offender on a career as a mental patient" (222). That is, madness is perceived, 
in Phyllis Chesler's words, as a "wish to 'step outside' culture" (87), to transgress social norms. And what can be more cultural than gender, one of the first - if not the first, according to Butler (1993)—markings in socialization? There have been many studies since the 1970s on how madness has been "feminized" since the end of the 19th century (Showalter 1987; Chesler 2005; Appignanesi 2008; Ussher 2011), and most twentieth-century definitions of madness are closely linked to the correct performance of gender, whether it be male or female (Appignanesi 7). However, the treatment of madness has been feminized (e.g.: infantilization, shock treatment, lobotomy), as stated by Showalter (210).

In her article "Women and Madness: The Critical Phallacy" (1975), Shoshana Felman concludes that "[m]adness, in other words, is precisely what makes a woman not a woman" ("Women and Madness" 8; her emphasis). She explains that traditional images of madness in Western culture, i.e., emotionality and irrationality, have been linked to "womanhood" since the 18th century, precisely in opposition to "manhood" understood as rationality-thus constructing "woman" as "Other". However, what we understand as "madness" in psychiatric terms, which is a lack of cultural referents when reading someone else's behaviour, is the absence of that "womanhood". In short, madness is the impossibility of reading a woman as a woman, what Felman terms "the lack of resemblance" ("Women and Madness" 8). This "acting" as a woman or not is directly linked to Judith Butler's theory of performativity. According to Butler, "'performativity' must be understood not as a singular or deliberate 'act', but, rather, as the reiterative and citational practice by which discourse produces the effect that it names" (Butler 2). Therefore, gender is not "performed" in one single act, but in a repetition of norms and practices since birth, equating sex with gender and gender with the subject, whereby the subject comes into beingthat is, render it "culturally intelligible", liveable (Butler 2-3) - , and which, in performing it, is reaffirming the discourse of gender. The fact that gender is cultural, and "womanhood" and "manhood" mean different things for different cultures can be seen in parallel to the cultural definition of madness. Thus, my claim is that madness can also be performative and much linked to gender.

This article intends to explore the performativity of madness viewed as an escape from gender in Janet Frame's second autobiographical volume, An Angel at my Table (1981). This thesis has been explored before by authors such as Mercer $^{1}$ (1993) in relation to societal expectations in general, but I intend to do so through a gender lens, following the work of Suzette Henke and Shoshana Felman. ${ }^{2}$ Another element that I will take into account for this analysis is the fact that An Angel at my Table belongs to the autobiographical genre, or, at least, it is presented as such. Therefore, in the second part of this article, I also intend to

\footnotetext{
${ }^{1}$ Gambaudo also discusses the performative aspect of madness in her analysis of Janet Frame's Faces in the Water (2012).

2 A similar contention about Charlotte Perkins Gilman's "The Yellow Wallpaper"'s reappropriation of the medical language of madness as a weapon against patriarchal oppression has been made by Gerardo Rodríguez Salas (2012).
} 
explore a question that has already been asked many times: why the mismatch between Janet Frame's fiction and her life writing? Specifically, I am referring to the gap in An Angel at my Table (1981) about the account of the many times she was committed to mental asylums for nearly ten years during the late 1940s and early 1950s. This gap has been noticed by many academics (Mercer 1993; Ash 1993; Lecercle, 2000; Boileau 2007) and Boileau has attempted to explain it following Lejeune's autobiographical pact. However, other critics such as Mercer have pointed out this gap as a flaw, deeming Frame's autobiographical work conservative and unsatisfactory, and have searched for a more faithful account of her stay in mental asylums in her novel Faces in the Water (1961) (Mercer 43-44). Faces in the Water is indeed described as a "documentary" (Frame, Faces vi) and was actually a mandatory read for nurses in New Zealand mental asylums for many years after it was published (Evans quoted in Gilbert et al. 20), although Frame cautions against reading the main character, Istina Mavet, as a fictionalized version of herself (Frame, Faces vi; Frame, Angel 228). However, Frame admits in An Angel at my Table: "were I to rewrite Faces in the Water, I would include much that I omitted because I did not want a record by a former patient to appear to be over-dramatic" (Angel 256), thus inextricably linking the two texts. In this paper, I argue that Janet Frame uses the autobiographical genre as a site to reconstruct her identity, after having had to give up her self-her bodily - since she did not fit the gender conventions of her society. Thus, remembering becomes a "re-membering" of the self (Henke 2000).

At the beginning of An Angel at my Table, there is a foreshadow of what is to happen to Janet ${ }^{4}$ when, on the train from her hometown to Dunedin, she passes by the psychiatric hospital where she will be committed, Seacliff: "there was a movement in the carriage as the passengers became aware of Seacliff, the station, and Seacliff the hospital, the asylum" (Frame, Angel 175; her emphasis). There is already a sense that only a thin line separates the right Seacliff from the wrong one, as if suggesting that it might be easy to end up in the latter by mistake. Indeed, in her hometown (north of Dunedin) becoming mad is known as being sent "down the line" and in Dunedin as being sent "up the line": the trip that Janet is undertaking is actually in between, right on that line, in a place that is neither her town nor the city, where borders are blurred and it is dangerous to linger:

Yes, the loonies were there; everyone looked out at the loonies . . . Often it was hard to tell who were the loonies ... We had no loonies in our family, although we knew of people who had been sent 'down the line', but we did not know what they looked like, only that there was a

\footnotetext{
${ }^{3}$ For the sake of convenience and space, in in-text citations I will use the cues "Faces" and "Angel" to refer to Faces in the Water and An Angel at my Table, respectively.

${ }^{4}$ I will use "Janet" to refer to Janet Frame as a character in her own autobiography and Frame to refer to the author/narrator, following Lejeune's distinction in "The Autobiographical Pact" (1975).
} 
funny look in their eye and they'd attack you with a bread knife or an axe. (Angel 174; my emphasis)

Although Janet's idea about madness responds to societal standards, such as identifying madness with danger ("they'd attack you with a bread knife or an axe") or an abnormal physical trait ("a funny look"), she is not sure about how to distinguish the loonies when the people in the train are looking at them. Ironically enough, she will feel this very lack of safety when she is committed to a mental institution: those who will seem dangerous and threatening will be the sane ones - the doctors that will give her ECT and will prescribe a leucotomy to cure her, her family and acquaintances forcing her to be "normal". Like in her fiction, Frame plays out the slight, artificial difference between the world of the sane and that of the insane, which are not so far away.

In the city, feeling utterly lonely and always afraid of rejection, Janet is "conscious always of boundaries of behaviour and feeling in [her] new role as an adult" (Frame, Angel 194). These boundaries mainly refer to the limits of her behaviour as an adult woman, which are, as some critics note, above all bodily boundaries (Oikkonen 2004, Merli and Torney, 1997). Janet, who more than anything aspires to be a "lovely girl, no trouble at all" (Frame, Angel 206), soon realizes that performing gender correctly is about the proper management of the female body and its sexuality. As Oikkonen claims, "society considers madness not as an illness but as bad behaviour, as women's refusal to hide their sexuality and to tame their threatening femaleness by subjecting their bodies to male control. In other words, madness is seen by society as the 'untamed' female body" (emphasis hers). In the portrayal of Janet's fear of the body, specifically the female body, Frame makes explicit the correlation between female sexuality and death.

Janet is ashamed of how she looks, embarrassed of her decaying teeth ${ }^{5}$ and her unruly hair, which make her undesirable as a woman. She eats very little, only when she is alone; hides away the chocolate wrappers she eats in secret; and eats leftover food without having her host aunt notice: "I was unable to revise my impression as the girl with the tiny appetite, and so I was often hungry" (Frame, Angel 182). The correct management of her appetite is part of the correct management of her body. She walks to the cemetery in the outskirts of the city to bury her sanitary towels instead of burning them at home or school, which seems to me not a "decision to control the borders of the body in her own way, not to hand them over to social surveillance" as Merli and Torney argue (70), but rather a more extreme way to cover up any symptom of womanhood in her body, to bury it to death in the same way that she hides and "kills" her appetite. While denying her body, she does not want to follow any of the examples of female sexuality around her.

\footnotetext{
${ }^{5}$ Teeth appear as a cause for Janet's shame at her unfeminine appearance and as a marker of her poverty, since she could not afford to go to the dentist to have them replaced for a set of fake teeth, something common in New Zealand at the time: "the general opinion in New Zealand was that natural teeth were best removed anyway." (Frame, Angel 238)
} 
On the one hand, her sister Isabel is an example of a full-blown female sexuality, which is frowned upon in the conformist New Zealand of the 1940s. She always has a boyfriend, swims, is loud and complains about the conditions in which the two sisters live at their aunt's home. She is told off at the teaching college because she wears a skirt printed with a giraffe. In fact, the principal tells Janet to influence her younger sister because "Isabel . . . was making a guy of herself both by her behaviour and by the clothes she wore" (Frame, Angel 202). Janet feels ashamed for her loud behaviour-for Isabel has no intention of being "a lovely girl, no trouble at all" - , but does follow her when she suggests they steal their aunt's chocolates, since the two girls are starving. However, Isabel's incorrect performance of her gender and her untamed sexuality are punished indirectly: she drowns in her twenty-first year, becoming what she did not bother to hide during her lifetime: literally, a body. The alternatives, though, do not seem promising for Janet: her mother is remembered as "an everlasting servant" (Frame, Angel 212), and, although she writes poetry, like Janet, it is always for her family, like everything else she does. Something similar happens with her schoolteacher, Miss Macaulay, whom she visits while at university. Janet realises that her former teacher has no further intellectual aspirations of any kind, and feels disappointed: "I was saddened by the knowledge that Miss Macaulay had been extracted from her place by the same domesticity that had denied my mother a sight of hers" (Frame, Angel 186). Both women have given up their sexuality and taken up female roles that please society, but these do not fulfil Janet either.

As Suzette Henke claims, "[g]ender is a cultural performance that [Janet] is unable to master and, indeed, refuses to practice in reiterative gestures of normative behaviour" (Henke 95). Thus, Janet attempts suicide in order to escape from her job as a teacher and from the expectations of society that her self and her body do not meet. The first time that she is committed to a mental institution, she feels "sheltered and warm" (Frame, Angel 223), away from teaching and her family and money problems and her "increasing sense of isolation in a brave bright world of brave bright people; away from the war and being twenty-one and responsible; only not away from [her] decaying teeth" (Frame, Angel 223). That is, the asylum becomes an actual physical shelter from the performance of sanity. As Gambaudo argues in relation to Faces in the Water, but which can as well be applied to An Angel at my Table, "[i]n emphasising the performative aspects of mental health, Frame gives representation to the constraints that underlie performances of sanity and to those other (mad) performances constraint denies." (46) Just as madness is a performance, so is sanity, and each put constraints that take a toll on the individual's identity and body.

Faced with the paradox of wanting to write and not conforming to the expectations for a woman of her time, but in constant need of validation from those around her, when Janet is diagnosed with schizophrenia she decides that she has finally found the status where being different is justified: "I was taking my new status seriously. If the world of the mad were the world where I now 
officially belonged (lifelong disease, no cure, no hope), then I would use it to survive, I would excel in it. I sensed that it did not exclude my being a poet" (Frame, Angel 234). In choosing to remain a poet, conscious of the well-known relationship between madness and creativity, she is not only choosing madness over sanity, but she is choosing madness over being a woman, understanding madness as Felman's "lack of resemblance" ("Women and Madness" 8). As Appignanesi notes, when "schizophrenia" became a very common diagnosis,

those labelled schizophrenic could easily enough develop a career path of craziness. Learning the illness behaviours that got attention from doctors and formed a bond with other patients was ... an inevitable part of life in a 'total institution'... . [T] he compliance it generates in patients . . . can lead to entrapment in a schizophrenic role and a pattern of recurrent institutionalization.

Being schizzy could all too easily become a way of life. (251)

When Frame describes how she felt about her new condition, she talks about "a feeling of loneliness but with a new self-possession" (Angel 234). And in fact, when she finishes her first "probation" period and she is declared sane for the first time, she acknowledges a "twinge of loss" (Frame, Angel 240), as if she had lost something in her identity that could help her survive her not following the norms: "I still had my writing, didn't I, and if necessary I could use my schizophrenia to survive" (Frame, Angel 251). Thus, schizophrenia becomes her "way of life". She plays out her character so well that she is soon admitted as a chronic patient, and realises that "[she] had woven [herself] into a trap, remembering that a trap is also a refuge" (Frame, Angel 253). Madness becomes the realization of her "wish to step outside of culture" (Chesler 87), the kind of exile that Sontag talks about in Illness as Metaphor (36). In this case, it is an exile from expected gender roles. As Suzette Henke argues, for Janet, madness becomes a "cloak of schizophrenic that functioned as a sheltering cocoon - a medically constructed identity bordering on the poetic, valorizing her difference and confirming her indifference to social conformity" (94-95): it protects her from other people's criticism, and allows her to be different-a writer, as she desires.

However, she will soon discover that the performance of madness renders her "an instant third person, or even personless" (Frame, Angel 225), and that she is trapped in that role. As a patient in a mental institution, she is denied an identity and reduced to be nothing more than what she had tried to avoid being: a body, not a person. According to Suzette Henke, following Foucault, "it is the 'very materiality' of the institution of incarceration that functions 'as an instrument and vector of power' to objectivize the body of a patient or prisoner" (94). We can note how the objectification of the patient shares some similarities with the social objectification of the female body in order to keep it within the boundaries. Being cured is thus linked to "taming" the body, to having it behave 
in the "proper", social way, a notion that stems from the "moral management" psychiatric tradition in the 19th century.

"Moral management" in the asylum can be traced back to the 18th century and was implemented after the Madhouse Act in Britain (1828), when mental illness began to be seen as a moral illness that needed treatment, rather than brutalizing and isolating patients like in Medieval times. "Moral insanity" was a term coined by James Cowles Prichard in 1835, and according to him, madness was: "a morbid perversion of the natural feelings, affection, inclination, temper, habits, moral dispositions, and natural impulses, without any remarkable disorder or defect of the intellect, or knowing and reasoning faculties, and particularly without any insane illusion or hallucination" (quoted in Showalter 29). That is, madness was seen as any kind of behaviour deemed abnormal or disruptive by community standards, and curing a patient meant making them fit for society again.

In the narrative, patients are reduced to mere objects, mistreated and humiliated, as Frame recalls her fellow companions in the asylum who had "no legal or personal identity - no clothes of their own to wear, no handbags, purses, no possessions but a temporary bed to sleep in with a locker beside it, and a room to sit in and stare . . Many patients confined in other wards of Seacliff had no name, only a nickname, no past, no future" (Angel 228). In treating them as objects (bodies), they are completely denied of an identity so that this can be remade anew, tailored to society. At the asylum, Janet is often compared to her "more normal" (tamed) fellow inpatients: "Nola's having her hair straightened, Nola's having a party dress, Nola's having a party-why not you too?" (Frame, Angel 264); and asked, after being offered a leucotomy, whether she would not just like to be normal and sell hats in a shop (Frame, Angel 264). These questions ring strikingly similar to the questions she is asked when she is temporarily discharged and lives her real life: "I had no answers to the simplest questions: where had I been working before I came to the laundry? Was I 'going out' with anyone? Why didn't I get my hair straightened?" (Frame, Angel 260) That is, questions regarding the management of her body and her sexuality. Frame makes explicit this correlation between life in the asylum and life outside of it in Faces in the Water: "if you can't adapt yourself to living in a mental hospital how do you expect to be able to live 'out in the world'? How indeed?" (Frame, Faces 42) Taming the body and making it fit for the "outside world" is the key task of the asylum. In fact, the second time that she is admitted to the mental hospital is when she has her teeth extracted. After this, she signs up for voluntary ECT treatment. Not only is she helpless regarding her life decisions, but she is toothless, with no power over her own body either outside or inside the asylum, and the extreme end of that "body management" arrives when she is prescribed a leucotomy: an operation that will change her brain forever - as it turns out, moral management is a rather bodily method.

Miraculously, right before she undergoes the operation, the doctor speaks to her, "to the amazement of everyone" (Frame, Angel 264), as she recalls. In addressing her, he is acknowledging her as a subject again. He informs her that 
she has won a literature prize for her first book of stories, The Lagoon, and that she will not undergo the leucotomy after all. Thus, her salvation is due to external prestige. However, the asylum system has completely eroded her sense of self: "after having been subjected to proposals to have myself changed, by a physical operation, into a more acceptable, amenable, normal person, I arrived home ... with the conviction at last that I was officially a non-person" (Frame, Angel 266). Indeed, after the reiteration of the performance of madness, its discourse has finally asserted itself: "[f] or I was now officially suffering from schizophrenia, although I had had no conversation with the doctors, or tests" (Frame, Angel 253). She has woven herself into her own trap, and she will not get out of it until a writer offers her a place to live and write: a room of her own, in Virginia Woolf's terms. The solution, therefore, is linked to material conditions, and so is her self-assertion: the moment that she accepts her own body as it is, without the pressures of gender and society, she feels alive again. She takes a picture of herself - "a proof that [she] did exist" (Frame, Angel 286) — without straightening her hair, although the hairdresser tells her that "her hair would never be attractive unless it was professionally straightened" (Frame, Angel 287). This picture is a testimony to her survival, and to what she has lost and gained in order to survive: "The finished portrait showed a healthy young woman with obvious false teeth, a smirking smile and a Godfrey chin. It was a fresh photo, of substance. Well, I was alive again" (Frame, Angel 287; my emphasis). According to Shoshana Felman, "survival is, profoundly, a form of autobiography" (What Does a Woman Want, 13). In telling how she has survived, what has been lost comes in the way. In fact, what Frame loses in order to become a writer is her sexuality, for the moment that she chooses to live with the homosexual writer Frank Sargeson, she has to give up her life as a woman of the time:

The price I paid for my stay in the army hut was the realisation of the nothingness of my body. Frank talked kindly of men and of lesbian women, and I was neither male nor lesbian ... I, who now looked on Frank Sargeson as a saviour, was forced to recognise through the yearning sense of gloom, of fateful completeness, that the Gods had spoken, there was nothing to be done.

In exchange for this lack of self-esteem as a woman, I gained my life as I wanted it to be. (Frame, Angel 299; my emphasis)

Following Shoshana Felman on autobiographical writing, Frame's An Angel At My Table "can only be a testimony: to survival. And like other testimonies to survival, its struggle is to testify at once to life and to the death - the dying - the survival has entailed" (What Does A Woman Want 16). This dying is what Frame has left behind: her female sexuality. This results, however, in acknowledging her body as it is and taking care of herself: just before Janet sets off for England to start her writing career, she knits herself a cardigan her family deems ugly and shapeless, but she wears it on her journey anyway. Just as she chooses her fate, she chooses her appearance, and dresses in something that will keep her body warm and comfortable, something that she has made for herself. The sweater 
may be seen as a metaphor for her writing, which has saved her from the operation and will become her means of life and protection. This sweater/writing is not tailored to the likings of everybody, but to hers only; it is protecting and life-affirming, and this is enough.

As Felman affirms, "the 'writing of a woman's death' is precisely the 'writing of a woman's life"” (What Does A Woman Want 16). I will now look at how Frame "redefine[s] and resubjectivize[s] the shattered self damaged by institutional abuse" (Henke 96) through life writing and particularly by the thoroughly noted elision of her experiences in mental asylums in An Angel at my Table. Frame did write fictionally about these experiences in novels such as Faces in the Water and Owls Do Cry, and critics wonder why she decided to go on and write an autobiography where she omits the actual experience in the asylums. Frame herself acknowledges this gap too: "[a]nd when I had been in hospital several months beyond the voluntary period and was declared a committed patient, that was the beginning of the years in hospital which I have already described, setting out only, as I have said, the actual events and people and places, but not myself, except for my feeling of panic simply at being locked up by those who reminded me constantly that I was "there for life" (Frame, Angel 253; my emphasis). She is referring to the fictional protagonist of Faces in the Water, Istina Mavet. Indeed, as Boileau notes,

confusion is fostered by the immediate correction 'except for,' which qualifies her presentation and places back in the foreground the representation of the self that had been denied, and the consequent interpretation of the text as partly autobiographical . . . Therefore the fictional account becomes one among other accounts of a reality that a single text could not entirely contain. (224; his emphasis)

Faces in the Water is autobiographical only in so far as the events are true, but lacks Frame as a subject-except her pain, which she places, in fact, elsewhere, for she did not feel as a subject. However, An Angel At My Table omits these events from the subject that the text aims to reconstruct. It is in fact only when she is not writing about herself (a fictionalized account like Faces in the Water) that she can describe the events at the asylum, but in her autobiographical writing it becomes impossible to contain that reality in order to establish (at least temporary, on the text) the subject as a whole, to restore the subject who has survived and now has the power to tell it: "[t]he act of lifewriting serves as its own testimony and, in so doing, carries through the work of reinventing the shattered self as a coherent subject capable of meaningful resistance to received ideologies and of effective agency in the world" (Henke xix). In not telling, she is reestablishing her subjectivity and gaining the agency that had been denied to her to decide who she wants to be, reshaping her identity and deciding what to tell and what to leave out. According to Frame, "[w]riting an autobiography, usually thought of as a looking back, can just as well be a looking across or through, with the passing of time giving an X-ray quality to the eye" (Frame, Angel 225). This goes hand in hand with Linda Anderson's affirmation that "the recognition of that memory could also provide a space in 
which the subject can create herself, or that it contains a future we have yet to gain access to, could also change the knowledge we already have" (12). Thus, life writing allows for a space for that which memory cannot contain and, at the same time, Frame avoids narrating the parts of her life where she felt dead, therefore choosing actively the knowledge about herself that she wants to share. Suzette Henke argues that "[t]hrough the artistic replication of a coherent subject-position, the life-writing project generates a healing narrative that temporarily restores the fragmented self to an empowered position of psychological agency" (xvi). After feeling repeatedly that she did not "have a 'place' in the world" (Frame, Angel 275) and been told that she had "what was known as a "history"' (Frame, Angel 262), Frame has knitted herself another kind of sweater: a new history of herself, through writing.

\section{WORKS CITED}

Anderson, Linda. Women and Autobiography in Twentieth Century: Remembered Futures. Hertfordshire: Prentice Hall Harvester Wheatsheaf, 1997.

Appignanesi, Lisa. Mad, Bad and Sad: A History of Women and the Mind Doctors. New York \& London: W. W. Norton \& Company, 2008. PMid:18569606

Ash, Susan. "“The Absolute, Distanced Image': Janet Frame's Autobiography." Journal of New Zealand Literature 11 (1993): 21-40

Boileau, Nicolas Pierre. "Places of Being: Janet Frame's Autobiographical Space." Auto/Biography Studies 22.2 (2007): 217-229.

Butler, Judith. Bodies That Matter: On the Discursive Limits of 'Sex'. New York \& London: Routledge, 1993.

Chesler, Phyllis. Women and Madness. Rev. Edition. New York: St Martins, 2005.

Felman, Shoshana. "Women and Madness: the Critical Phallacy." Diacritics 5.4 (1975): 2-10. https://doi.org/10.2307/464958

---. What Does a Woman Want?: Reading and Sexual Difference. Baltimore \& London: The John Hopkins University Press, 1993.

Foucault, Michel. Madness \& Civilization: A History of Insanity in the Age of Reason. Trans. Richard Howard. New York: Vintage, 1988.

Frame, Janet. An Angel at my Table. London: Virago, 2008.

---. Faces in the Water. London: Virago, 2009.

Gambaudo, Sylvie. "Melancholia in Janet Frame's Faces in the Water." Literature and Medicine. 30.1 (2012): 42-60.

https://doi.org/10.1353/lm.2012.0008. PMid:22870608

Gilbert, Emily, et al. "Battles From Below: A Literature of Oppression." Geography and Literature 38.1 (1996): 19-28. 
https://doi.org/10.1007/bf00209116

Henke, Suzette A. Shattered Subjects: Trauma and Testimony in Women's Life Writing. New York: Palgrave Macmillan, 2000.

Lecercle, Jean-Jacques. "Folie et Litterature: de Foucault à Janet Frame." La Licorne 55 (2000): 293-304.

Lejeune, Philippe. "The Autobiographical Pact." On Autobiography. Ed. Paul J Eakin. Trans. Katherine Leary. Minneapolis: University of Minnesota Press, 1989. PMCid:PMC1031850

Mercer, Gina. "“A Simple Everyday Glass': The Autobiographies of Janet Frame." Journal of Commonwealth Literature 11 (1993): 41-48.

Merli, Carol, and Torney, Kay. "Dangerous Margins: The Body and Art in Janet Frame's Autobiographies." Women's Studies 27 (1997): 63-83. https://doi.org/10.1080/00497878.1997.9979195

Oikkonen, Venla. "Mad Embodiments: Female Corporeality and Insanity in Janet Frame's Faces in the Water and Sylvia Plath's The Bell Jar." Helsinki English Studies: Electronic Journal 3 (2004) Web. 15 Sept. 2016. <http://blogs.helsinki.fi/hes-eng/volumes/volume-3-special-issueon-literary-studies/mad-embodiments-female-corporeality-and-insanityin-janet-frames-faces-in-the-water-and-sylvia-plaths-the-bell-jar-venlaoikkonen/>.

Rodríguez Salas, Gerardo. “Just as a Scientific Hypothesis': The Literary Language of Madness in Charlotte Perkins Gilman's 'The Yellow Wallpaper'." Odisea 13 (2012): 105-112.

Showalter, Elaine. The Female Malady: Women, Madness \& Culture, 18301980. London: Virago, 1987. PMCid:PMC254138

Sontag, Susan. Illness as Metaphor. New York: Farrar, Straus and Giroux, 1978.

Ussher, Jane M. The Madness of Women: Myth and Experience. New York: Routledge, 2011.

Received: 20 April 2016

Accepted: 8 November 2016 